The Geographical Journal of Nepal

Vol. 13: 91-106, 2020

Doi: http://doi.org/10.3126/gjn.v13i0.28154

Central Department of Geography,

Tribhuvan University, Kathmandu, Nepal

\title{
Geo-hydrological hazards induced by Gorkha Earthquake 2015: A Case of Pharak area, Everest Region, Nepal
}

\section{Buddhi Raj Shrestha ${ }^{1,4^{*}}$, Narendra Raj Khanal ${ }^{1,4}$, Joëlle Smadja ${ }^{2,4}$, Monique Fort ${ }^{3,4}$}

\author{
${ }^{1}$ Central Department of Geography, Tribhuvan University, Kirtipur, Kathmandu Nepal \\ ${ }^{2}$ Centre for Himalayan Studies, UPR 299. CNRS, 7 rue Guy Môquet, 94800 Villejuif, France \\ ${ }^{3}$ Université Paris Diderot, GHES, Case 7001, UMR 8586 PRODIG CNRS, Paris Cedex 75013, France \\ ${ }^{4}$ ANR-13-SENV-0005-02 PRESHINE \\ (* Corresponding Author: biraj323@gmail.com)
}

Received: 8 November 2019; Accepted: 22 January 2020; Published: March 2020

\begin{abstract}
Nepal experienced disastrous earthquake events in 2015. The first one (magnitude of 7.8) with epicenter in Barpak, Gorkha district, occurred on $25^{\text {th }}$ April 2015, followed by another event (7.3 magnitude) on 12th May 2015, with epicenter in $19 \mathrm{~km}$ south east of Kodari, Sindhupalchok district. Those earthquake events induced different types of geo-hazard and they are widely distributed and caused serious damages and losses. This paper discusses the types of geo-hazards induced by these Gorkha and Sindhupalchok earthquake events and the losses and damages from those events; and the future risk from those geo-hazards in Pharak area covering $305 \mathrm{~km}^{2}$ in Solukhumbu district, Nepal. Satellite images of before and after the events were used to map landslide, debris flow, landslide dam and other geomorphic changes after earthquake. Information on the losses, damages and future risk were collected through focus group discussion, key informants' interview, observation, and measurement. A total of 79 landslides, 13 rockfalls, 5 debris flow and one site of river damming were identified and mapped. The losses and damages included private and public buildings, cultivated land, crops and other infrastructure such as trails, canals for hydropower plant. The losses and damages associated with landslide and debris flow induced by earthquake is comparatively higher than the losses and damages from other geomorphic hazards such as rock fall and landslide dam and landslide dam outburst flood. The risk from those geo-hazards induced by earthquake is also high. Community mobilization with activities of regular monitoring of those hazards, skill development for rescue operation, design and implementation of mitigation measures are some of the efforts necessary for better management of disaster risk.
\end{abstract}

Key words: Gorkha earthquake, geo-hazards, damages, mitigation and adaptation. 


\section{Introduction}

Geo-hazards are events caused by climate/geological/geo-morphological features and processes that present severe threats to humans, property, and the natural and built environment. Typical examples include earthquakes, floods, landslides, volcanoes, avalanches, and tsunamis (Alcántara-Ayala and Goudie, 2010;). The Encyclopedia defines that geo-hazard is a geological state that may lead to widespread damage or risks, which are geological and environmental, conditions and involve long-term or short-term geological processes. Earthquake is such a geo-hazard that can initiate other hazards like landslides, snow avalanche, floods, and tsunamis.

Nepal is a mountainous country and there are many types of hazards resulting in the loss of life and properties occur in the countries. The frequently occurring hazards are earthquake, floods, landslides, debris flow, glacial lake outburst flood, landslide damming and its outburst, windstorm, hailstorms etc. (Shrestha et al., 2016). Many of the hazards are associated with each other's and one hazard induces many other types of hazards resulting in losses and damages.

Earthquakes are one of the main triggering factors of landslides. Largest earthquakes are capable to trigger thousands of landslides (Keefer, 1984). Keefer also had studied an earthquake-induced landslide distribution - the 1989 Loma Prieta, California event (moment magnitude, $\mathrm{M}=6.9$ ), which generated landslides in a total area of about $15,000 \mathrm{~km}^{2}$. Most of these landslides were occurred in an area of about $2000 \mathrm{~km}^{2}$ in the mountainous terrain around the epicenter. In southwest China, due to its complex geological and geographical conditions, many strong earthquakes occurred frequently and are accompanied by a large number of landslides that were associated with serious damage (Yi Wen \& Xu, 2002; Xu Zhang \& Wen, 2005; Chen, Q. F., \& Wang, K. 2010; Wen, B.P., Wang, S.J., Wang, E.Z., \& Zhan, J.M,2004). For example, the destruction caused by landslides triggered by the Wenchuan Earthquake (magnitude of 7.9) in China in 2008 was unexpected and shocked the world (Yi Wen \& Xu, 2002). This earthquake not only caused several landslides of more than 15000 (Yin, Y., Wang, F., \& Sun, P., 2009) and it also triggered some infrequent huge landslides along the seismic faults. Daguangbao landslide, with estimated volume of 750 million $\mathrm{m}^{3}$, is the largest one among the individual landslides triggered by Wenchuan earthquake (Huang \& Li, 2009).

Another earthquake (magnitude of 7.6) occurred in 2005 within the Hazara-Kashmir Syntaxis along the Balakot-Bagh Fault (also known as Muzaffarabad fault), with a maximum vertical displacement on the fault of about $5 \mathrm{~m}$. (Hussain et al., 2006). As a result, thousands of very dense bands of landslides were triggered resulting in destruction of infrastructure. The landslides were mostly triggered along the fault rupture trace. 
Hattian Bala rock avalanche was the largest landslide associated with the earthquake which destroyed a village and blocked the tributaries of Jhelum River, thus creating a dam. A total of around 2500 landslides were triggered due to earthquake and mostly the landslides occurred along the hanging wall block of the fault (Sato et al., 2007).

Every year, different countries face different magnitudes of earthquakes resulted huge loss of life and properties. The devastation caused by them depends on their magnitude. According to USGS, The Haiti Earthquake (2010) of magnitude 7.0 causing the death of more than 300 thousand people, Tangshan Earthquake of China (1976) causing the deaths of more than 240 thousand, are the major earthquakes recorded to date. The total fatalities and damages caused by them are even higher. Land sliding from the earthquake blocked many rivers and impounded lakes behind landslide dams. Landslide dams, followed by flooding behind the dam and outburst floods when the dam fails generate one of the most common forms of natural disaster in steep and narrow mountain valleys (Schuster \& Costa, 1986; Evans, Hermanns, Storm, \& Scarascia, 2011).

Nepal experienced a major earthquake with magnitude of 7.8 on 25 April 2015 (12 Baisakh, 2072 B. S.). The epicenter of this earthquake was at Barpak, Gorkha district. Therefore, it is also referred to Gorkha Earthquake 2015. The major earthquake was followed by more than 30,000 aftershocks out of which 400 were greater than magnitude of 4.0 (www.seismonepal.gov.np). On the other hand, four aftershocks were greater than 6.0 magnitude scale in which the struck of 17 days after the major shock had the magnitude of 7.3 on $12^{\text {th }}$ May 2015 (29 Baisakh, 2072 B. S.), with epicenter in $19 \mathrm{~km}$ south east of Kodari, Sindhupalchok district. The catastrophic earthquake had resulted over 8,800 casualties and over 22,000 injuries together with displacement of 100,000 people. And it was estimated that these earthquakes have affected the lives of eight million people, almost one-third of the population of Nepal. The estimated total value of disaster effects (damages and losses) caused by the earthquakes is NPR 706 billion or its equivalent of US\$ 7 billion (NPC 2015a). Almost all sectors - social sectors (housing and human settlement, health, education and cultural heritage), productive sectors (agriculture, irrigation, commerce, industry, tourism and finance), Infrastructure sectors (electricity, communications, community infrastructures, transport and water and sanitation) and Crosscutting issues (governance, disaster risk reduction and environment and forestry) were seriously affected.

The earthquake activated or reactivated numerous landslides, which caused major damage to settlements and infrastructure, and it was clear that these posed a continuing risk. An international volunteer group comprising scientists from the USA, Europe, and the region mapped the landslides using satellite images and paying special attention to 
those blocking rivers (Kargel et al., 2015; Sharma \& Shrestha, 2015; Collins \& Jibson, 2015). Based on their reconnaissance claimed the hazard of Langtang as debris avalanche type and identified the existence of 60 landslide dams induced by Gorkha earthquake sequences within the seven districts under study. Kargel, et al. (2015) identified 3,455 landslides induced by Nepal's 2015 Gorkha Earthquake some of which buried or blasted villages or blocked rivers or roads. The same paper discusses about relationships of landslide distribution with slopes and large peak ground accelerations; there is also a strong association with the tectonically down dropped block; the uplifted block contains few landslides

Most of the literatures have focused in severely earthquake affected districts or west of Ramechhap districts like Gorkha, Sindhupalchok, Rasuwa, Dhading, Nuwakot etc. The landslides and other geomorphic hazards associated with the earthquake after $25^{\text {th }}$ April in other districts like Solukhumbu district which was also affected severely were not reported. Therefore, this study aiming to fulfill the knowledge gap was came out. This study tries to find out the earthquake and earthquake induced geo-hazards, losses, damages, spatial distribution and local knowledge on mitigation and adaptation in Pharak area in Solukhumbu district.

\section{The study Area}

Geographically, Pharak area is located (Figure 1) from $86^{\circ} 31^{\prime}$ to $86^{\circ} 54^{\prime}$ 'East longitude and from $27^{\circ} 39^{\prime}$ to $27^{\circ} 48^{\prime}$ North latitude. It is located about $90 \mathrm{~km}$ northeast from Kathmandu has covered 305 sq. $\mathrm{km}$ area. Everest region consists of three sub-regionKhumbu (Namche and Khumjung VDC) in the north, Pharak (Chaurikharka) in the middle and Solu Salleri in the south. The study area covers only Pharak, middle part of the region. Several large and small settlements lie along the trekking trail. The major settlements of the trails are Surke, Lukla, Ghat, Phakding, Manjo and Jorsalle etc. The altitude of the study area ranges from 2000 to $6400 \mathrm{~m}$ the climatic condition ranges from subtropical in lower altitude to temperate and alpine. Higher Himalayan Zone consisting of high-grade metamorphic and weathering-resistant rocks such as gneiss, migmatite, schist, quartzite, and marble. The cultural landscape of different ethnic groups are Sherpa, Rai, Magar Newar and Chhetri. There are 960 households with 3,709 people inhabited in this area. Among this 1,872 are male and 1,837 are female population settled in the study area. Because of rapid increase of tourism business, occupation is shifting from agro-pastrolism to tourism as more people and more establish lodges, hotels, pack animal services (Rai , 2017). The study area covers total of $395 \mathrm{sq} \mathrm{km}$ with covering $49 \%$ snow land, $25 \%$ barren land $20 \%$ with forest and $1.57 \%$ with bush and remaining $3.5 \%$ land by built up, river and lake. 


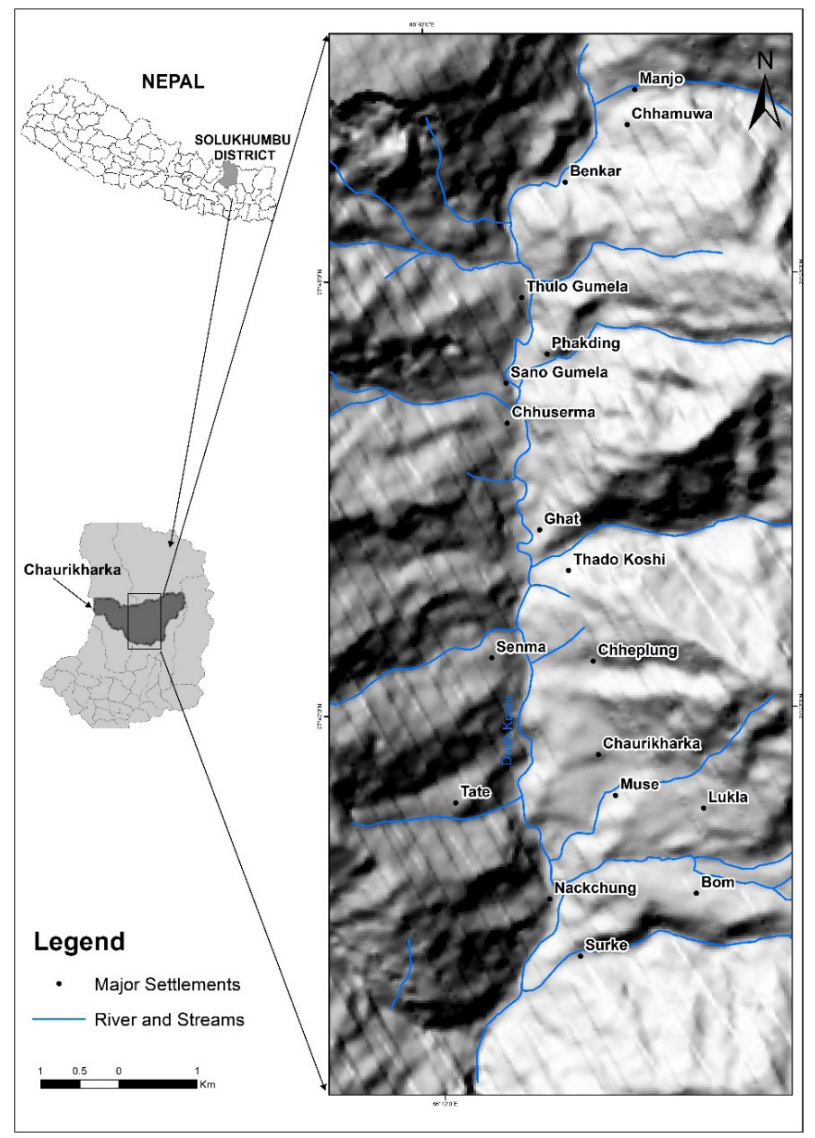

Figure 1: Location of Study Area

\section{Methods and Material}

This study utilizes both primary data and secondary data. A step by step process were adopted. At the first step all the features: landslide, debris flow, rock fall and river damming were identified in satellite image taken in SPOT 62012 (Dec. 3) before earthquake and SPOT 7, 2015 (Nov. 17) after earthquake (Figure 2). Identified features were digitized and prepared the maps and these maps were used for field verification. The field visits consist of three activities: confirmation of landslides mapped through observations, collection of data in the year of occurrences by interviewing key informants and measurement of length and width of landslides, collection on information of the losses and damages, future risk and adaptation and mitigation activities of local people through focus group discussion. We scheduled field visits and GPS devices were used to record the location of existing landslides and the possible hazardous spots. Important historical 
landslides locations were recorded during the field visit. Focus group discussion was conducted in two settlements named Ghat and Phakding with 12 participants from Ghat settlement and 9 participants from Phakding settlement. Key information interview was conducted in different settlements and included school teacher, businessman, housewife and VDC secretary. Checklists were prepared for focus group discussion and key informants' interview. The geo-morphological characteristics of length, width and area of these landslides were recorded for 15 landslides. The collected data were analyzed, and the hazards maps were prepared in Arc GIS 10 Software.

\section{Results and Discussion}

\section{Earthquake Induced Hazards}

A total 79 landslides, 13 rock falls, 5 debris flow and one site of river damming were traced and mapped. There was a total of 20 landslides existed before the earthquake, 39 landslides were initiated during the earthquake and 20 landslides after the earthquake (May 12 ${ }^{\text {th }}, 2015$-April 31 ${ }^{\text {st }}, 2016$ ). A total of 3 rock falls existed before the earthquake, 5 rock falls initiated during the earthquake and 5 rock falls after the earthquake. Similarly,2 debris flow existed before the earthquake and 2 debris flow developed during the earthquake and 1 debris flow after the earthquake and 1 river damming was developed between Tok Tok and Benkar village (Fort et al., 2019 (Table 1).

Table 1: Types and extent of earthquake induced hazards

\begin{tabular}{|l|r|r|r|r|}
\hline \multirow{2}{*}{\multicolumn{1}{c|}{ Types }} & \multicolumn{3}{c|}{ Occurrence } & Total \\
\cline { 2 - 5 } & Before & During & After & 79 \\
\hline Landslide & 20 & 39 & 20 & 13 \\
\hline Rock Fall & 3 & 5 & 5 & 5 \\
\hline Debris Flow & 2 & 2 & 1 & 1 \\
\hline River Damming & & 1 & & \\
\hline
\end{tabular}

Source: Field Survey, March, 2017 (Before: Identified from SPOT 6, 2012 before earthquake During: Verified through observation and information obtained from local people After: Identified from SPOT 7, 2015 (Nov 17) and verified through observation and information obtained from local people.)

\section{Topographical characteristics of earthquake induced hazards}

Topographically many of the landslides (77 out of 79) are in the bottom part, 1 landslide is located in middle part and 1 landslide is located in ridge to bottom part of the topography. Similarly, many of (12 out of 13) rock falls are located in bottom part, 1 
rock fall is located in middle part of the topography. A total of 4 debris flows are located in bottom part, 1 debris flow is located in middle part of the topography (Table 2).

Table 2: Topographical characteristics of earthquake induced hazards

\begin{tabular}{|l|r|r|r|r|}
\hline \multirow{2}{*}{\multicolumn{1}{c|}{ Types }} & \multicolumn{5}{|c|}{ Topographical location } \\
\cline { 2 - 6 } & Bottom & Middle & Ridge to Bottom & Total \\
\hline Landslide & 77 & 1 & 1 & 79 \\
\hline Rock Fall & 12 & 1 & 0 & 13 \\
\hline Debris Flow & 4 & 1 & 0 & 5 \\
\hline
\end{tabular}

In terms of aspects many of the landslides (32 out of 79) are in south aspect, 27 landslides are in east aspect ,1 landslide in west aspect. Similarly, most of the rock falls 7 out of 13 are in south aspect, 5 rock falls are in east aspect and 1 rock fall is in west aspect. There are 3 debris flow located in south aspect, 2 debris flow are in east aspect (Table 3 ).

Table 3: Location of hazards in different aspects

\begin{tabular}{|c|c|c|c|c|c|}
\hline \multirow[b]{2}{*}{ Types } & \multicolumn{4}{|c|}{ Aspects } & \multirow[b]{2}{*}{ Total } \\
\hline & East & West & North & South & \\
\hline Landslide & 27 & 16 & 4 & 32 & 79 \\
\hline Rock Fall & 5 & 1 & 0 & 7 & 13 \\
\hline Debris Flow & 2 & 0 & 0 & 3 & 5 \\
\hline
\end{tabular}

Many of landslides 47 out of 79 are initiated in slope between 20-40, 20 landslides are in below 20, eight landslides are in 40-60 and four landslides are in above 60. Similarly the highest number of rock fall that is (7 out of 13) are initiated in slope between 20-40, then after 5 rock falls below 20, and 1 rock fall is in between 40-60. In terms of debris flow 2 debris flow initiated in between 20-40, 2 debris flow are in below 20 and 1 debris flow is in between 40-60 (Table 4 and Figure 3). 
Table 4: Hazards distribution on slope

\begin{tabular}{|l|r|r|r|r|r|}
\hline \multirow{2}{*}{ Types } & \multicolumn{4}{|c|}{ Slope Category in Degree } & \multirow{2}{*}{ Total } \\
\cline { 2 - 6 } & Below 20 & \multicolumn{1}{|c|}{$\mathbf{2 0 - 4 0}$} & $\mathbf{4 0 - 6 0}$ & Above 60 & \\
\hline Landslide & 20 & 47 & 8 & 4 & 79 \\
\hline Rock Fall & 5 & 7 & 1 & & 13 \\
\hline debris Flow & 2 & 2 & 1 & & 5 \\
\hline
\end{tabular}

Besides landslides, rock fall, debris flow and river damming, the changes in water sources is another type of hazards reported by the local people. According to them one springs was existed before earthquake and the water utilized by local people was dried out and there were no significant losses due to dried out of water. This was reported from Muse village near Lukla and later local people find out another spring source below the previous water source.
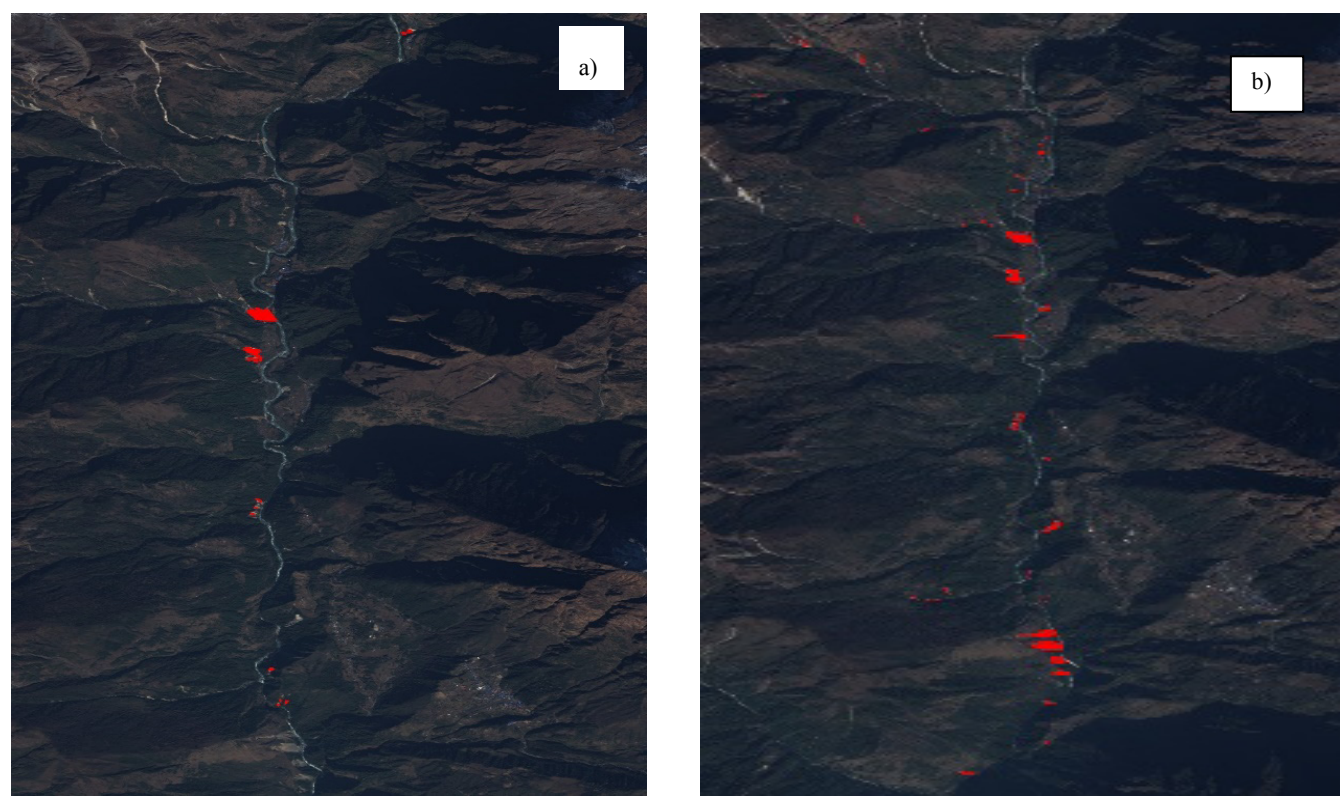

Figure 2: SPOT satellite images used to map landslides and other geomorphic hazards a) SPOT 6 image December 3,2012 before the earthquake) b) SPOT 7 image (November 17,2015) after the earthquake. 


\section{Losses and Damages by Gorkha Earthquake in Pharak Area}

After the main event of Gorkha earthquake of 7.8 magnitude on $25^{\text {th }}$ April 2015, the aftershock event with epicenter in east of Kodari of 7.3 magnitude resulted huge amount of losses and damages of properties. A total of nine houses and sheds, 1,250 meters with trekking trail, One hydropower reserve tank and 130 meter water pipe were destroyed by landslides. Local people of Chuserma and Surke reported 80 meter of water pipe of Chuserma hydropower and 50-meter water pipe of Surke hydropower was destroyed by landslides. Rock fall has destroyed 30 meter trekking trail and debris flow destroyed two houses and 30 meter trail (Table 5).

Table 5: House and infrastructures damages and losses by earthquake induced hazards

\begin{tabular}{|l|r|r|l|}
\hline \multicolumn{1}{|c|}{ Types } & \multicolumn{1}{c|}{ House/Shed } & \multicolumn{1}{c|}{ Trail (m) } & Hydropower \\
\hline Landslide & 9 & 1250 & 1 reserve tank 130 meter pipe \\
\hline Rock Fall & 0 & 30 & \\
\hline Debris Flow & 2 & 30 & \\
\hline Total & 11 & 1310 & \\
\hline
\end{tabular}

Source: Field Survey, March 2017

The maximum crops and cultivated land have damaged by landslide. A total of 0.56 hectare khet land with 0.28 hectare bari land, 3,300 kg potato, $970 \mathrm{~kg}$ maize, $670 \mathrm{~kg}$ buckwheat and $1480 \mathrm{~kg}$ of wheat were destroyed. Rock fall has damaged 0.05 hectare bari land and $200 \mathrm{~kg}$ potato, $50 \mathrm{~kg}$ maize. Similarly, debris flow damaged 0.05 hectare bari land with $300 \mathrm{~kg}$ of potato (Table 6). Two significant landslides found in Nackchung (Figure $4 \mathrm{~b}$ ) village west of Lukla and destroyed cultivated land ,shed and trial and these landslides run across the main trail from Lukla to Nackchung down to the river, isolating villagers from the main valley. They had to be flown to Lukla where they stayed for three months while the trail was being repaired (Fort, M., Smadja, J., Khanal, N. R., \& Shrestha, B. R., 2019). Another landslide from Phakding landslide (Figure $4 \mathrm{~d}$ ) right side of the Dudh koshi river has destroyed the major trekking trail (Lukla -Namche). The examples of house damaged and canal damaged are shown in (Figure 4 $\mathrm{a}$ and $\mathrm{c})$. 


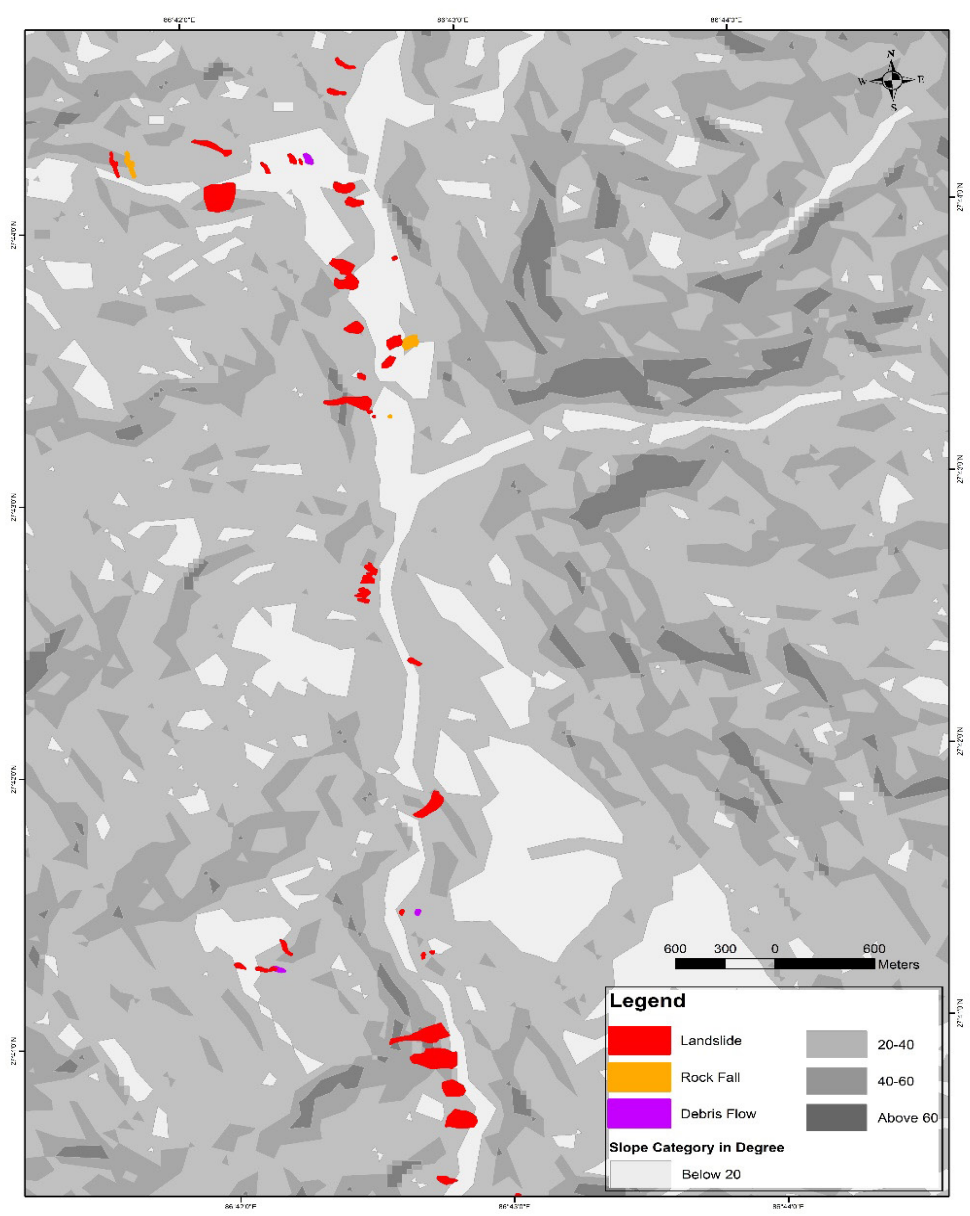

Figure 3: Distribution of earthquake induced landslides, rock falls and debris flow superimposed in slope map

Table 6: Crops and Cultivated land damages and losses by earthquake induced hazards

\begin{tabular}{|c|c|c|c|c|c|c|c|}
\hline \multirow[t]{2}{*}{ Types } & \multicolumn{2}{|c|}{$\begin{array}{l}\text { Cultivated } \\
\text { Land (ha) }\end{array}$} & \multicolumn{4}{|c|}{ Crops (Kg) } & $\begin{array}{l}\text { Total } \\
(\mathrm{Kg})\end{array}$ \\
\hline & Bari & Khet & Potato & Maize & Buckwheat & Wheat & \\
\hline Landslide & 0.28 & 0.56 & 3,300 & 970 & 670 & 1,480 & 6,420 \\
\hline Rock Fall & 0.05 & & 200 & 50 & & & 250 \\
\hline Debris Flow & 0.05 & & 300 & & & & \\
\hline Total & 0.38 & 0.56 & 3,800 & 1,020 & 670 & 1,480 & 6,670 \\
\hline
\end{tabular}

Source: Field Survey, March 2017 


\section{Estimated Economic Losses by Earthquake Induced Hazards}

Table 7 shows the highest amount of estimated economic losses of 103.79 million (92\%) by landslide. A total of 4.7 million in house and shed, 0.49 million in crops, 35 million cultivated land, 2 million in hydropower were lost by landslide. The estimated economic losses by debris flow is 7.53 million (7\%) out of 113.429 million. It is estimated that 1.5 million from house and shed, 0.03 million from crop, 3 million from cultivated land, 3 million from trail due to earthquake induced debris flow. The total estimated economic losses by another earthquake induced hazard rock fall is 2.109 million (2\%) which has lost 0.019 million in crops, 2 million in cultivared land and 0.09 million in trekking trail.

Table 7: Estimated Economic Losses by Earthquake induced Hazards

\begin{tabular}{|c|c|c|c|c|c|c|c|}
\hline \multirow[b]{2}{*}{ Types } & \multicolumn{5}{|c|}{ NPR Million } & \multirow[b]{2}{*}{ Total } & \multirow{2}{*}{$\begin{array}{c}\text { Total } \\
(\%)\end{array}$} \\
\hline & \begin{tabular}{|c} 
House/ \\
Sheds
\end{tabular} & Crops & $\begin{array}{c}\text { Cultivated } \\
\text { Land }\end{array}$ & Trail & Hydropower & & \\
\hline Landslide & 4.7 & 0.49 & 35 & 61.6 & 2 & 103.79 & 92 \\
\hline Rock Fall & & 0.019 & 2 & 0.09 & & 2.109 & 2 \\
\hline $\begin{array}{l}\text { Debris } \\
\text { Flow }\end{array}$ & 1.5 & 0.03 & 3 & 3 & & 7.53 & 7 \\
\hline Total & 6.2 & 0.539 & 40 & 64.69 & 2 & 113.429 & 100 \\
\hline
\end{tabular}

Source: Field Survey, 2017

\section{Mitigation and Adaptation}

Local people perceived that geo-hazards like, landslide, rock fall etc. occur in their settlements. Yet, the 2015 Gorkha earthquake had resulted damages and losses in the study area and it damaged trail and bridges. This event had changed the mindset of local people to construct earthquake resisting buildings and other infrastructures too. People think that tree plantation, wall construction and bio-engineering could reduce the effect of landslide, rock fall and debris flow (Figure $5 \mathrm{a}$ and $\mathrm{b}$ ). Villagers on average felt that a geological hazard would likely occur at their settlements frequently and did not know the mitigation action clearly during a geological hazard. Local people felt that there is no more open spaces and safe land during the disaster period and lacking disaster preparedness. Respondents think that building and other infrastructures should be constructed earthquake resisting 

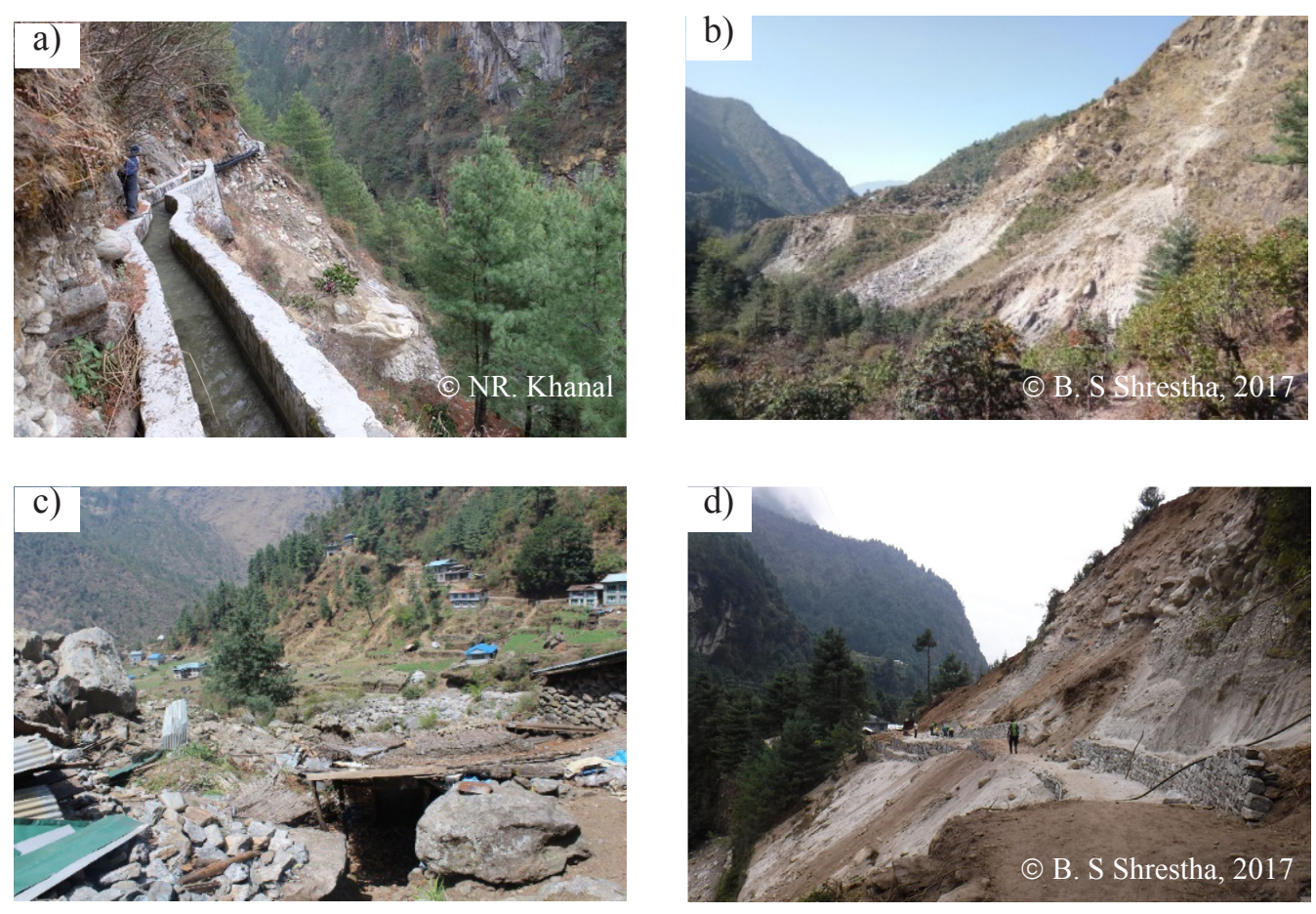

Figure 4: Earthquake induced hazards losses and damages in study area. a) Canal damage at Manjo by landslide b) landslide induced at Nackchung village c) Destroyed stone masonary building and collapse crops and cultivated land at Surke village south of Lukla, d) Trail damage by Landslide north of Phakding.
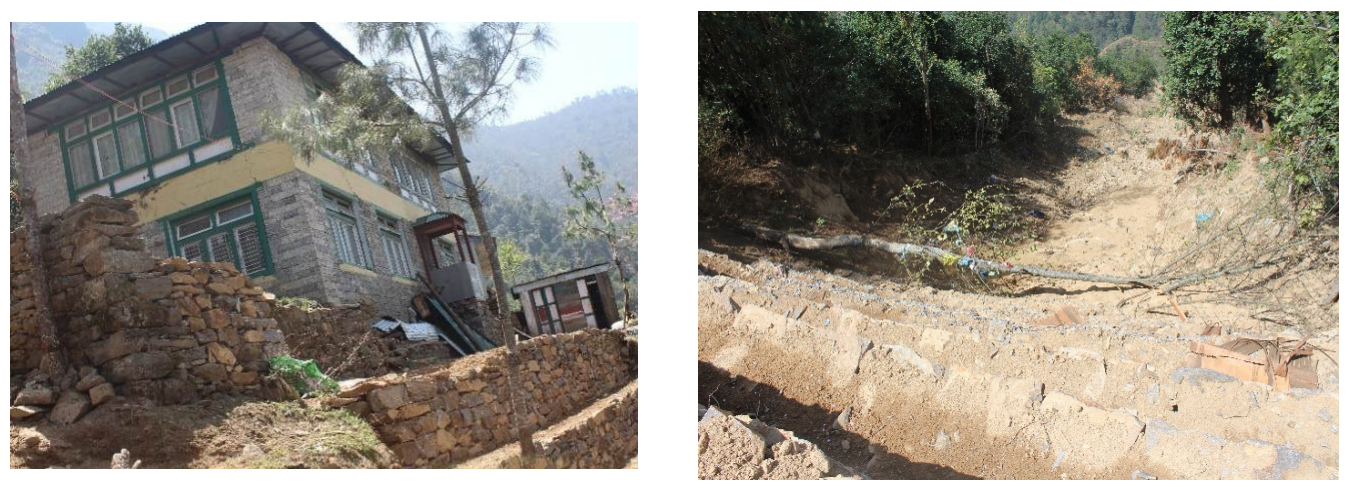

Figure 5: Wall constructions to mitigate house and trail at Surke village a) landslide affected house upper part b) wall construction (stone and mud) to control headward extension of landslide. 


\section{Discussion}

Our observations are similar to those carried in the areas mostly affected by the earthquake of $25^{\text {th }}$ April 2015 in the west of Khumbu region (Collins and Jibson, 2015; Kargel et al., 2015; Gnyawali et al., 2016; Valagussa et al., 2016). The study by National Planning Commission (NPC, 2015a, b) shows that the earthquakes had an impact on all sectors: social, productive, infrastructure and cross-cutting. The destruction was widespread, covering residential and government buildings, heritage sites, schools and health posts, rural roads, bridges, water supply systems, agricultural land, trekking routes, and hydropower plants. An attempt was made to estimate the share of earthquakeinduced geo-hydrological hazards, especially landslides and debris flows, in the total per capita disaster loss district-wide in the seven most heavily affected districts. The study area is not included in seven severely district, but study area was affected by different geo-hazards induced by Gorkha Earthquake. Inner valleys are highly vulnerable to earthquake-induced landslides, and many hydropower stations and trunk roads were heavily damaged by the 2015 landslides (Chiaro et al., 2015).

The previous study shows that besides monsoon rainfall, earthquake is one of the major causes to induce landslides, rock fall, debris flow etc. After Gorkha earthquake, the study by Kargel et.al. (2015) identified 3,455 landslides induced by Nepal's 2015 Gorkha Earthquake some of which buried or blasted villages or blocked rivers or roads. The same paper discusses the relationships of landslide distribution with slopes and large peak ground accelerations. There is also a strong association with the tectonically down dropped block; the uplifted block contains few landslides. Similarly, study by Collins \& Jibson (2015) based on their reconnaissance claimed the hazard of Langtang as debris avalanche type and identified the existence of 60 landslide dams induced by Gorkha earthquake sequences within the seven districts under study. Landslide dam was also observed in the study area, but it was very small, and the impact is not significant.

\section{Conclusion}

Gorkha Earthquake sequence of May 12 ${ }^{\text {th }}, 2015$ (7.3 magnitude) induced geo-hazards like landslides, rock falls, debris flow and river channel constriction and damming and changes the availability of water from springs, The observation indicates that most of the landslides, rock falls and debris flows are in bottom slope, east and southern aspects.

The main effect of the shaking was collapse of buildings (private and public) and cracking of land and roads. The earthquake-induced geo-hazards also led to loss and damage of buildings, cultivated land, but in addition, there was a marked impact on standing crops and infrastructure such as bridges, trails, roads, hydropower projects, 
and irrigation canals. The secondary effect of the damage from geo-hazards is likely to be comparatively much higher than that of the direct earthquake impact in terms of loss of livelihoods, blocking of movement of people, goods, and services, and loss of revenue from trade and energy supply. The mitigation measure could be construction of earthquake resisting building, tree plantation, wall construction and bio engineering community mobilization with activities of regular monitoring of those hazards, skill development for rescue operation, design and implementation of mitigation measures are some of the efforts necessary for enhancing the capacity of local people and reducing the risk of geo-hazards.

\section{Acknowledgements}

This work was carried out with French funding from ANR-13-SENV-0005-02 PRESHINE, and with the support of the Centre for Himalayan Studies, CNRS (France).

\section{References}

Irasema Alcántara-Ayala \& Andrew S. Goudie (eds.). 2010. Geomorphological hazards and disaster prevention. London: Cambridge University Press.

Chen, Q. F., \& Wang, K. (2010). The 2008 Wenchuan earthquake and earthquake prediction in China. Bulletin of the Seismological Society of America, 100(5B), 2840-2857.

Chiaro, G., Kiyota, T., Pokhrel, R. M., Goda, K., Katagiri, T., \& Sharma, K. (2015). Reconnaissance report on geotechnical and structural damage caused by the 2015 Gorkha Earthquake, Nepal. Soils and Foundations, 55: 1030-1043.

Collins, B. D., \& Jibson, R. W. (2015). Assessment of existing and potential landslide hazards resulting from the April 25, 2015 Gorkha, Nepal Earthquake Sequence. Menlo Park,CA,USA: Geological Survey Open -File Report.

Costa, J. E, \& Schuster, R. L. (1988). The formation and failure of natural dams. Geological Society of America Bulletin, 100, 1054-1068.

Evans, S.G., Hermanns, R.L., Storm, A.L., \& Scarascia, M.G (eds.). (2011). 'Natural and artificial rockslide dams, lecture Notes in Earth Sciences. Heidelberg: Springer.

Fort, M., Smadja, J., Khanal, N. R. \& Shrestha, B. R. (2019). Landslides and other damage to buildings and infrastructures following the April-May 2015 earthquake sequence, Solukhumbu District, Eastern Nepal. Journal of Nepal Geological Society,. 59: 95-106 
Gnyawali, K. R., Maka, S., Adhikari, B. R., Chamlagain, D., Duwal, S. \& Dhungana, A. R. (2016). Spatial Implications of Earthquake Induced Landslides Triggered by the April 25 Gorkha earthquake Mw 7.8: Preliminary analysis and findings. Intern. Conf. on Earthquake Engineering and Post Disaster Reconstruction Planning, 24-26 April 2016, Bhaktapur, Nepal. Proc, 50-58

Hack, R., Alkema, D., Kruse, G., Leenders, N., \& Luzi, L. (2007). Influence of earthquakes on the stablity of slopes. Enginnering Geology, 91: 4-15.

Huang, R. Q., \& Li, W. L. (2009). Analysis of the geo-hazards triggered by the 12 May 2008 Wenchuan Earthquake, China. Bulletin of Engineering Geology and the Environment, 68: 363-371.

Hussain, S., Nisar, A., Khazai, B. \& Dellow, G. (2006). The Kashmir earthquake of October 8, 2005: Impacts in Pakistan. Earthquake Engineering Research Institute Special Paper, 8.

Kargel, J. S., Leonard, G. J., Shugar, D. H., Haritashya, U. K., Bevington, A., Fielding, E. J., et. al. (2015). Geomorphic and tectonic controls of geo-hazards induced by Nepal's 2015 Gorkha Earthquake, SCIENCE Express (Forthcoming).

Keefer, D. K. (1984). Landslides caused by earthquakes. Geological Society of America Bulletin, 95: 406-421.

Keefer, D. K. (2000). Statistical analysis of an earthquake-induced landslide distribution — the 1989 Loma Prieta, California event. Engineering Geology, 58: 231-249.

NPC. (2015a). Post disaster needs assessment: Key Findings (vol A). Kathmandu, Nepal: Government of Nepal, Nepal Planning Commission.

NPC. (2015b). Post disaster needs assessment: Sector Reports (vol B). Kathmandu, Nepal: Government of Nepal, Nepal Planning Commission.

Rai, D. (2017). Tourism development and economic and socio-cultural consequences in Everest Region. Geographical Journal of Nepal, 10: 89-104.

Sato, H. P., Hasegawa, H., Fujiwara, S., Tobita, M., Koarai, M., Une, H., \& Iwahashi, J. (2007). Interpretation of landslide distribution triggered by the 2005 Northern Pakistan earthquake using SPOT 5 imagery. Landslides 4, 113122

Schuster, R. L., \& Costa, J. E. (1986). Effects of landslide damming on hydroelectric projects. In Proceedings $5^{\text {th }}$ International Association of Engineering Geology Congress, Buenos Aires, 295-307.

Sharma, E., \& Shrestha, A. B. (2015). Nepal 2015 Earthquake: Uncertainty prevails in the Himalayan Arc. Proceeding of Indian National Science Academy, 557-560. 
Shrestha, A. B., Bajracharya, S., Kargel, J., \& Khanal, N. R. (2016). The Impact of Nepal's 2015 Gorkha Earthquake Induced Hazards. Kathmandu: ICIMOD.

Statistical analysis of an earthquake-induced landslide distribution - the 1989 Loma Prieta, California event. (n.d.).

Valagussa, A., Frattini, P., Crosta, G. B., Valbuzzi, E. (2016). Pre and post 2015 Nepal earthquake landslide inventories. In: S. Aversa, Cascini L., L. Picarelli, C. Scavia (Eds), Landslides and Engineered slopes: Experience, theory and practice. Proc. of the 12th Intern. Symposium on Landslides (Naples, Italy, 1219 June 2016, 1957-1964.

Wen, B. P., Wang, S. J., Wang, E. Z., \& Zhan, J. M. (2004). Characterstics of rapid giant landslides in China,. Landslides, 247-261.

Xu, X. W., Zhang, P. Z., \& Wen, X. Z. (2005). Features of active tectonics and recurrence behaviors of strong earthquakes in the western Sichuan province and its adjacent regions. Seismol.Geol, 446-461.

Yi, G. X., Wen, X. Z., \& Xu, X. W. (2002). Study on recurrence behaviors of strong earthquakes for several entireties of active fault zones in Sichuan-Yunnan region, Earthquake research in China, 267-276.

Yin, Y., Wang, F., \& Sun, P. (2009). Landslide hazards triggered by the 2008 Wenchuan earthquake, Sichuan, China. Landslides, 6 (2): 139-152. 